\title{
Between Dark Black and Light Brown. Discourses and Ethnic Identities among Afrodescendant Boys and Girls in School Context in Bogotá
}

\section{Entre el negro oscuro y el café claro. Discursos e identidades étnicas entre niños y niñas afrodescendientes en contexto escolar en Bogotá}

Received: 31 - Jan - 12 / Accepted: 7 - May - 12

\author{
Sandra Soler \\ Profesora Doctorado en Educación \\ Universidad Distrital Francisco José de Caldas \\ Bogotá, Colombia \\ E-mail: ssoler73@hotmail.com
}

\begin{abstract}
There is a felt need to understand the way ethnic identities are constructed by Afrodescendant boys and girls aged 6-12 in school contexts in Bogotá as there is little research in such specific context and topic in Colombia. This research report proposes a discourse analysis and social psychology approach to tackle such problem. Thus this paper seeks to identify the discursive mechanisms that allow us to know how identity processes emerge from the acceptance or denial of ethnicity; mechanisms that may lead or have an effect on discursive adaptation, resistance or negotiation. Findings suggest that children begin early their ethnic self-identification from the color of the skin, whereby they differentiate a wide color range, tending towards whitening. Children have different degrees of ethnic appraisal that go from pride to rejection. In inter-ethnic relations, they tend to deny or minimize the conflict, and there is a tendency to avoid speaking about it. Children identify the cause of the problem as a quantitative issue, as they are minority in Bogotá. In inter-ethnic dynamics, some children accept the stereotypes assigned to them, others reject them, and others scoff at them.
\end{abstract}

Key words: discourse, identities, self-identification, appraisal

\begin{abstract}
Resumen
Hay una necesidad para comprender la forma en que las identidades étnicas son construidas por los niños y niñas afrodescendientes de 6-12 años en el contexto escolar en Bogotá, como hay poca investigación en el contexto específico de este tema en Colombia. Este informe de investigación propone un análisis del discurso y el enfoque de la psicología social para hacer frente a tal problema. Así, este documento busca identificar los mecanismos discursivos que nos permiten conocer cómo los procesos de identidad surgen de la aceptación o la negación de origen étnico, los mecanismos que pueden llevar o tener un efecto sobre la adaptación discursiva, la resistencia o negociación. Los resultados sugieren que los niños comienzan a principios de la auto-identificación étnica por el color de la piel, por el que se diferencian una amplia gama de colores, tendiendo a blanquear. Los niños tienen diferentes grados de valoración étnica que van desde el orgullo al rechazo. En las relaciones interétnicas, tienden a negar o minimizar el conflicto, y hay una tendencia a evitar hablar de ello. Los niños identifican la causa del problema como una cuestión cuantitativa, ya que son minoría en Bogotá. En la dinámica entre los grupos étnicos, algunos niños aceptan los estereotipos asignados a ellos, otros los rechazan, y otros se burlan de ellos.
\end{abstract}

Palabras Clave: El discurso, las identidades, la auto- identificación, la apreciación. 


\section{Introduction}

Some years ago, by the 1990's, I began working with the Inga native community dwelling in Bogotá; I conducted field work by visiting Bogotá schools attended by boys and girls of this community. My concerns were the social interactions established in the school between teachers and students and between students themselves. I was shocked by what I then perceived as "suffering" of boys and girls at school (Soler 2003). Some years later, I began working with Afrodescendant communities concerning the topic of racism. I analyzed the school context, but from the perspective of school texts and the representation of Indians and Afrodescendants (Soler 2007, Soler \& Pardo 2008). From this work, I had the chance to provide advice to two undergraduate theses of students who wanted to analyze the ethnic interactions at school. Semistructured interviews prepared by the students and field notes were used (Santiesteban 2005, Molina E Vargas 2009). Such material revived my interest in inter-ethnic relations in schools and the way boys and girls were constructing their ethnic identities over the years. With students' consent, I summed up those interviews and present here an approximation to the understanding of the ethnic identities of Afrodescendant boys and girls in the school context of Bogotá, pointing out, however, the limitations derived from working with interviews that were not conducted by me, and the fact of dealing with interviews with very young boys and girls (ages 5 to 12). My approach is a qualitative analysis which ultimate purpose is not to review or prove theories on identities, but to propose some theoretical and discussion elements from the data, i.e. boys' and girls' voices.

\section{On the concept of identities}

As indicated by Stuart Hall (1996) in the introduction to his influential text Cuestiones de identidad cultural, "a huge discursive boost was recorded in the last years about the concept of identity, while it was subjected to a rigorous critique" (1996:13). It is not the interest of this research report to deepen into that discussion, but to clarify which is going to be the locus of enunciation in this work, from the theoretical and methodological point of view. Following Hall, I accept this is about deconstructing the term of identity rather that rejecting it. Therefore, I will not start with an a priori definition, but instead pointing out some of the characteristics of identities I will assume.

I begin stating that, as it has been in fact mentioned ad nauseam, there are no essential, unassailable or ahistorical identities. I follow the idea of fragmented identities under construction and tension. This allows decentering the questions on identity where, paraphrasing Hall, more than wondering Who am I? or Where do I come from?, it is preferable to question what we are able to become, how we have been represented through history and how such a representation has an effect on the way we could represent ourselves (ibid.: 18). I assume then that identities are constructed from the relationship with others, being relational since they account for differentiation and marking practices of us with respect to others. Therefore, authors such as Restrepo (2007) indicate the importance of understanding identity and difference as two sides of the coin which have no same value. Such relationship is determined by power, social, cultural and political hierarchies. This makes difference become the synonym of submission, exploitation or domination (Hall, cited by Restrepo, 2007: 27). Identities are however the ring where all these power relations are fought, because subjects bargain, reject or resist them. For Hall (1996), identities constitute the seaming line between subjection and subjectivation: "an identity is a seaming line, an articulating point, 
a concrete moment between: (1) discourses and the practices that constitute social locations or subject positions (woman, youngster, Indian, etc.) and (2) the processes of subjectivity production leading to accept, modify or reject such locations or positioning of the subject" (cited in Restrepo 2007: 30). Consequently, as Hall says, a study on identities "should not begin with the subject, but as a description of the suturing effects, the effect on the bond of the subject with the structures of sense" (Hall, 1996: 20).

I also assume that the construction of identities arises with practices, and especially through discourse, understood as a double practice: even though it is a form of doing itself, it is also through it that realities are constructed, as Escobar expresses: "it is a practice constitutive of any action, relation, representation or dispute in the domain of the social" (ibid. 27). The entrance to discourse emerges, then, mediated by the power relations that rule the social, and where the question of identity becomes a relevant aspect to consider agency.

\section{Social identities}

Speaking about social identity requires locating it in the field of interpersonal relations and decentering it from the individual aspect where it is generally placed. Social psychology pioneered this identification. Henri Tajfel, by the middle of the 70's, began to get interested in the development of local identities among individuals and explained it from psychosocial processes such as categorization and appraisal.

For Tajfel (1984) identity is part of the self-concept that derives from the relation of the person with certain categories or social groups. The self-concept is defined by him as a cognitive structure formed by the processes of categorization of the self and others based on similarities and differences. According to Tajfel (1984), categorization is one of the fundamental processes in the construction of social identities: "the social identity of a person is related to the knowledge of his/her belonging to certain social groups and to the emotional meaning and appraisal resulting from this belonging" (cited in Garrido E Álvaro: 392). Social identity is not only limited to the belonging to social groups but to comparative processes carried out by the person between the groups he/she belongs to and the other groups. From this comparison emerges an appraisal process that will determine the belonging and the relations that exist and might be established with those groups. The person will tend to stay in the group if this contributes to his/ her identity positively, otherwise, the person will tend to leave it or the person will try to change his group's appraisal or the situation causing the negative appraisal.

\section{Ethnic identities}

According to social psychology, there are different types of identities, including ethnic identity, referred to the sense of belonging to an ethnic group and to the portion of emotional, action and thinking processes derived from the acknowledgement of one's own ethnicity (Smith, 2002). Social psychologists also distinguish ethnic group and ethnicity. The former is defined as the one "distinguished by having certain common cultural features, but different to the ones of other human groups" (Duncan $\&$ Powel, 1988, p. 19, cited in Smith, 2002) and the second as the concrete fact of being born within a particular ethnic group, without exclusion of the possibility of belonging to two ethnic groups or more. While ethnicity is the objective "marker" of belonging to an ethnic collectivity, ethnic identity points at the subjective meaning of belonging to such ethnic group(s) (ibídem.). Conceiving off identities the way aforesaid entails reflecting upon a number of methodological issues which are tackled below. 
Methodological frames focused on avoiding generalizations or homogenization of subjects and groups are required. In that sense, it is preferable to opt for lay down singularities, particularities and differences, without forgetting that it is precisely there where the use of concepts such as identity becomes dangerous, as it is associated to the identical, the similar, and the equal. Now, if we adopt the assumption that identities are not essential, but constructed, then the methodology should point out how such construction occurs, what the historical trajectories and tensions are in particular moments, without forgetting the causes and reasons for their formations, which could allow us to speak, for example, of the socalled strategic essentialisms, that would respond to particular political reasons of ethnic groups.

Finally, if identities are discourse and they are built up through discourses, they are the place where identities are worth analyzing. We share the narrative turn because, as Bruner states "at the end we become the autobiographical narratives by which we account for our lives" (1994:694). Working with narratives supposes the recognition of the power of the oral word; this supposes an esthetic sense. Working with narratives stems from the fundamental principle that the other is important and that he/she has something to say that is also important and that one is eager to listen to him/her.

\section{Analysis}

The corpus is composed of 10 interviews of 5 to 12 years boys and girls attending mixedrace schools. I rely upon two series of interviews, one conducted in 2005 by a student preparing her undergraduate thesis work. These interviews were carried out with boys and girls of low and middle economic conditions, studying at different educational institutions, both public and private. The second series of interviews is constituted by five interviews conducted in 2007 by two students also preparing their undergraduate work. The interviews were accompanied by ethnographic work and field notes. In the case of the second series of interviews, the interviewers conducted their teaching-practicum at the school were those boys and girls were attending to, so there was a high degree of familiarity with the interviewees.

We identified interviewees' categorization and appraisal processes and the discursive dynamics that accounts for the identification, conflict or resistance processes. We then discuss our findings. The data analysis process was conducted having in mind both the theoretical framework and also the emergent categories obtained after studying research participants' answers. The analysis started off by pinpointing children's self-identification strategies. This refers to the ways participants used to name themselves: negro, brown, mild light brown. Once self-identification through name selection was pinned down, value-attribution was determined either positively or negatively. After this, the inter-ethnic relationships were established. Such relationships ranged from stereotype-acceptance to conflict. Category naming was achieved using research participants' own words.

\section{Self-identification}

\section{Color metonymy}

Boys and girls use different ethnic categories to speak of themselves. However, there is an early proof of identity based on the physical identification determined by skin color and other traits such as features and hair type. This first identification rules the categorization and could be described as a metonymic process where race is equaled to skin color, as identified by Santiesteban (2005). This is expressed by several children: 
A: People of your race?

B: Yes, of my race, because colored people...

A: What color do you think you are?

B: Well, look at me ...

A: I look at you, but I want to do an exercise... if you could choose, what would you say you are: Afrodescendant, brown, black, Nigger, Other, Which one?

B: Short, because I'm black, like my mom, my dad and my brothers and sisters.

The child does not hesitate to identify race and color. Faced with the interviewer's question, he expresses what is evident in the answer in terms of the senses: it is just about watching to identify color.

\section{Color variation}

Identifying color as a racial issue, however, does not mean that there is unity of criteria. Children identified themselves with a wide range of colors from dark black to light brown, where the dark black color often acquires negative connotations and light brown represents what is positive and desirable. These classifications would seem to be a residue of the logic of the caste society implanted during the colonial times, where people acquired social status according to skin pigmentation.

\section{I'm black}

In the varied mix of colors identified by the interviewees, some of them identify themselves as blacks. This is the case of Juan:

A: ... you are Afrodescendant, Brown, Black, Nigger, Other? Which?

B: I don't know, I think l'm black, because that's my color, isn't it? Also, that's the way people call me when they don't know my name or sometimes my classmates, but I like more when they call me sweet little black (laughing).
Juan resorts to skin color for selfidentification. He recognizes himself as black, accepting the external categorization attributed to him.

\section{I'm a cool brown}

In the chromatic scale acknowledged by the children, some of them do not identify themselves as blacks, but as belonging to a lighter color. In Miguel's words:

A: ... you are Afrodescendant, brown, black, Nigger? Other? Which one?

B: I am a cool brown (laughing)

\section{Almost brown}

Another name to be found is the one used by Ronaldo, who questions the fact that white children do not identify color differences:
A: And why were they bothering him? Do you know?
B: ...
A: Because he told me that some children... he was alone and some children started telling him black. Didn't he tell you that?
B: No (gesture)
A: Why do you think they told him that?
B: Because as we are almost brown, then... then...
A: Who are almost brown?
B: It's because we are almost brown, they told him... they told us... I'm also called black.

\section{Mild light brown}

Once children classify themselves as browns, this seems to be the point of departure to identify other colors drawing on white as the unmarked color, the color with positive traits.

$B:$ Yes, that is, not like my skin color.

A: And the people who are... people who have your skin color, how do you call them?

B: Eh... mild light brown.

A: Mild light brown... For example, your 
aunt here (pointing to the aunt, who is present) how would she be? Would you say she is...?

B: Mild dark brown.

A: Or your parents...?

$\mathrm{B}$ : My dad is mild dark brown and my mother is... like... almost light... it's like my brother's skin color. It means, I don't know how to call it very well.

A: Ah... but...

B: It's like... like... he is a bit lighter.

A: A bit lighter. Would you say that all at home are the same skin color?

B: No

A; No... Are they all different?

B: It means, I took after my father's skin color more or less.

A: Is it lighter than your mother's, or darker?

B: No, it's darker than my mother's. And my little brother took after... after my mother's skin color.

\section{Ethnic appraisal}

Appraisal is located in the field of the affective space and includes positive or negative judgment of individuals or groups by the mere fact of belonging to a group. Children's attitudes range from one end to the other, marked by the pride or rejection of the ethnic condition.

\section{Pride}

In children's discourses there seems to be a correspondence between self-identification within the color categories and the attitudes or appraisal of color. Those identified as blacks tend to appraise this condition better than those denying the color and prefer other less marked ethnic categorizations. However, to a certain extent, denying the skin color implicitly shows an appraisal of rejection.

Children seem to give importance to different stereotypes; thus, very young children assume as proper and real the characteristics attributed along history to blacks: dancing, being good athletes and being jokers.

\section{Acceptation of ethnic stereotypes}

Pride is sometimes due to different causes. There is pride related directly with stereotypes, understood as the set of traits or characteristics attributed to a group and its members.

A: How do you feel being an Afro?

B: Very well, I'm different to the others and I like it; besides, people always say I dance and I look like Michael Jackson, well the one who tells me most is my ma.

Miguel feels proud of his ethnic condition, because it makes him different to the others and approaches him to the stereotype of the black dancingstyle. Later on in the interview, Miguel reinforces this stereotype when he says:

A: Do you think you're good at dancing because you are an Afro or why?

B: Well, of course, it's because we black carry the music in our veins and we make good steps, you see, and we make things little whites can't do no matter how much they try.

A: What kind of things blacks do that whites don't?

B: ... playing basketball very well, running fast, in races and everything, don't you see that little blacks from Africa always win?, besides, Michael Jackson' steps can be done only by blacks; whites get lost (laughing), really.

Miguel repeats that it is his Afro condition which makes him good at dancing and also includes other skills such as sports. Facts speak by themselves as shown by his question 'Don't you see that little blacks from Africa always win?' This appears to be finally the reproduction of hegemonic representations, product of the historical domination gone through by the Afrodescendant people. 


\section{Painted blacks}

Miguel introduces here an important element: the existence of true blacks and painted blacks referring to those who do not comply with his stereotypes:

\section{A: Painted how?}

B: Well, look, painted are the black who are black on the outside, but don't do the things we bl... I mean, Afros do. Right?

\section{Historical pride}

Even though children are not very familiar with African history they have learnt they come from a strong, brave race that went through a lot of injustice and this makes them proud of their past and their origins:

A: How do you feel in general being black, as you said?

B: Ah, I really like it, I know we come from the Africans, while the whites don't even know where they came from like that (laughing), no, I'm serious, with my dad I read about the history of blacks in Africa and they had a very hard time, they were slaves and that, and they say we must study very much to be successful and not being enslaved and let's say ... I like my skin color rather than pale like that (pointing at the interviewer and smiling).

\section{Regional pride}

Sometimes historical pride is also connected with a more regional pride whereby children yearn for their places of origin where all are equal, or at least equal to them.

A: Jaime and where is that surname from?

B: Mainly people from Chocó.

A: Are you from Chocó?

B: Yes, jahh! That's the most fantastic land.

A: Do you think so... why?

B: Yes, because, oof, of course, yes, because... well, people, all are like us and nobody humiliates anybody for money, you don't have too much, but enough, you go out with your friends to the river, you play bottle checkers in the afternoon on the streets and we walk barefoot every time... (looking upwards), yes, great.

This identification is very important for children because when recalling their places of origin they feel satisfaction and pride of their racial condition. Positive emotions pervade their discourse as in the case of Jaime above, a very shy boy and isolated by the group. The idea of the origin surrounds them, of that time and space where all were equal, without distinctions of race or color. In that sense, the idea of returning back is recurrent as compared to Bogotá, where racism and discrimination are children's daily bread.

\section{Rejection}

\section{Rejection by the canons of beauty}

Although, children in general have a positive self-perception, gender comes to occupy a significant role. Girls are more subjected to the issue of the canon of beauty that elites have historically established as dominant: the pattern "white equals to beauty". Under this logic, the whitening process begins, psychologically starting from the denial of one's own skin color and physically by the assumption of the characteristics of the dominant group such as skin whitening or hair straightening.

Girls, from a very early age, when in contact with media and through the interpersonal relations with members of the dominant white groups perceive these logics, establish comparisons, question their beauty and feel inferior, as in María's case:

A: Could you describe me your mom?

B: Yes.

A: How is she like?

B: She is short, almost like me, $\mathrm{mmm} .$. 
she's got big brown eyes, she is a little white, has nice hair and long nails... what else... I don't know... she's a little white.

A: Is your mom a little white?

$B$ : Yes (leaning her head down).

A: Does it bother you?

B: Sometimes.

A: Why?

$\mathrm{B}$ : Because there are people, when they know my mother is white or know me, they think I'm adopted or say ugly things because I'm different to her, it means, I'm black, so to say...

María is a 7 year old girl is the daughter of an Afrodescendant father and a white mother. María establishes a comparison with her mother and she assumes that her own traits, being different, make her ugly:

A: How do you feel about belonging to an Afrodescendant community?

B: Well, the fact is I'm bothered by being like this, and I don't like it, sometimes I feel bad, because the other girls are all pretty and I am not.

A: Why do you say you're not pretty?

$B$ : Because of my hair and some laugh at me and when they make fun of a boy about me, he gets angry at me as a way of punishment, I reckon I'll never have a boyfriend.

María assumes that because of her Afrodescendant condition, more specifically, due to her skin color, she is not pretty like the other girls, and her hair is a mitigating factor, as she repeats:

A: What do your brothers and sisters say?

B: Nothing, well the one aged 13 says nothing and he tries to help me sometimes, and wants me to tell him when they bother me, but my other brother, aged 11, hummm... he bothers me and calls me smoke hair and crazy hair sometimes when I just get up of bed, because my hair gets tangled a lot, but I don't know what to do, because it's not my fault.
A: Would you like to have a different hair?

B: Yes, like my mom's that is straight, so Fernando wouldn't bother me.

Straight hair becomes then the ideal hair associated to beauty and white as the unmarked element in inter-ethnic relations.

\section{Rejection by phenotypic non-identification}

Some boys also reject being called Afrodescendant or blacks, but not for beauty issues as in girls, but for the stereotyped phenotypical traits that would identify the black. In Jaime's words:

A: Your classmates here consider you an Afro, did you know that?

$B$ : Yes, because my dad is Afro, but I took after my mom who isn't, but, well, I don't like them to call me Afro because my face is not like theirs... do you understand? Neither my hair.

A: No, I don't understand. How are Afro faces and hair, then?

B: Well, wide, big nose and mouth and the hair is quite funny, and mine is not like that, but I like them.

A: Is it annoying to you to call you Afro?

B: Yes, because they don't understand it seems so, but l'm not Afro, they're just misled because I'm somewhat dark, but I'm brown, not black.

Traits such as nose and mouth shape and the type of hair constitute identifying elements associated to the black. The color range acquires sense again. Black constitutes the negative pole.

\section{Ethnic identity dynamics}

I use the term dynamics to point out this back-and-forth movement, in order to indicate the aspect of process rather than stativity, acceptance or mere assimilation. 
Inter-ethnic relations:

\section{Conflict denial}

There is a double denial in the interviews. Firstly, a tendency to deny inter-ethnic conflicts emerges and, secondly, there is denial to speak about them. The topics of the interviews were initially aimed at the family and the neighborhood, and then they focused on school, personal relations and friendship or group relations. Most of the children declared they did not have any problem when they began establishing relations with the student groups. Others said they did not remember. However, later in the dialog they introduce the conflict issue unintentionally, when asked for clarification, they refuse to talk about it, conflicts tend to be minimized and justified.
A: Have you got any trouble at school with people? ... Have they bothered you by something?
B: No (gesture)
A: Sure?
B: No (gesture)
A: Ah... and if they bothered you by something... Why would they bother you?
B: Because I'm black.
A: Do you believe they could bother you because of that?
B: Yes (gesture)
A: And, why do you think so?
$B$ : Because they already have.
A: Who? Tell me...
B: Other children from other courses, last year...
A: Could you tell me what happened to you?
B: ...
A: Don't you want to tell? Are you frightened?
B: ...
A: Well, if you don't want to tell me, well, let's talk about another thing. Tell me, for example, what you do in vacations...
B: (sigh) Ah....well, fun things.

In this interview, Raúl repeatedly denies having been bothered by his classmates, he however points out that he could be bothered by being black, as it has in fact happened to him sometimes. In other interviews, when compelled to acknowledge the conflict, he places it in the past, a remote past that takes him away from the harshness of accepting the conflict as something present and daily at school. The refusal to talk about the issue is so strong that the interviewers had to change the topic in several opportunities and in one opportunity it became the reason to end the interview.

B: Ah, because I'm always bothered by them.

A: How do they bother you?

$B$ : Just bothering.

A: And what do they tell you?

$B:$...Me? Different things.

A: One for example:

B: One? They call me black... and so on... and then they come and tell me... and make up things.

A: What do they make up?

B: Different things... Is the interview over?

A. Yes, the interview is over.

Raúl is the youngest boy, he's 6, maybe this is why it is harder for him to talk about the topic. When asked about the conflict, he does not deny, he states that his classmates are always bothering him for being black. He does not give details or facts. He decides to end the interview because of the interviewer's insistence.

\section{They don't annoy me, but others}

Some children deny conflicts with classmates. They end up indicating it has not happened to them, but to others:

A: Have you ever been rejected by classmates because of your ethnicity?

$B$ : The truth is I get along with almost everyone, but some other children do not with some girls in the class because they keep saying: Oh, no, I won't sit beside that black, because he smells 
bad and so on, but this is a lie, because they don't smell bad, but they don't have their group so they are bullied. I certainly get well with Nicolás, besides I already have my "parchecito" (group) they don't bother me, but I don't like others to bother the other Afros in the class, but if I get into that, they're going to bother me too, so I rather not get into trouble, because I have a bad temper ...

As we will see soon, there is a trend to minimize the conflict by ascribing it to gender relations, where girls become fool and this is the cause for rejection.

\section{Refusal to talk about conflict}

Once children accept having been or being bothered at school, they continue the denial process, showing resistance to talk in detail about conflicts. This is, maybe, a mechanism of selfdefense that prevents us from reviving painful episodes. This is the case of Tania.

A: You say there is no racism, that you are very happy in your class and so on, but you feel anyhow that it would be better to be only with brown people...

B: Yes, madam.

A: Is there something that bothers you deep... in your class?

B: In my class... no, well, no.

A: Sure?

B. Yes

A: Really sure? Remember that you are completely safe here. Nobody knows me in your school, and nobody knows you in my university, so don't worry.

B: (10) ... Ah, yes, some classmates who came recently, for example, to my class. Yes? They mistreat everybody, because... (10) Because she is new, then she hasn't caught up with the environment, but no, because she's been here for a long time, she's going to be here one month, and if she keeps treating us badly, well, I don't think so...

A: How many are they?
B: Eh... they're two: Luz Edith and Katherine, they're two new girls. They both are... they mistreat whoever gets in their way, that this and that... one day I was playing, and I didn't mean to push her, we were playing tag and, then... she came and told me Ah! Get away, you black! And this and that!

Tania begins denying racism against her, but after long silences, she ends up recognizing that some classmates treat her badly because of her ethnic condition. Silences are indicators of the dramatic and painful nature of the situation, as well as the fact of not answering verbally to the questions, but nodding or shaking her head. Likewise, Tania refrains from telling the exact words that constitute the insult, and shortens with the expression "and this and that", discursive mechanism also recurrent in other children.

\section{Conflict minimization}

Once the conflict has been acknowledged, children tend to minimize or justify it with different arguments such as gender conditions or perception mistakes:

A: When you began studying here, did you have any problem to get in touch by the fact of being an Afrodescendant?

B: Mmm?, I don't know, I barely remember, but there were some girls who were foolish and they said they were scared by me because I was black, but it was just joking, and we were very small.

A: Do you remember how you felt like on that day?

B: Yes, (lowering his head), but I don't like to remember ...

A: It means, you don't want to tell me?

B: No, not that, it was long time ago... it's that when I came here everything was new and so, and those girls seemed not to have seen a little black before and as soon as I came, they got stunned and the teacher made me sit on the desk beside one girl and she started 
crying, (his countenance changes to a state of apparent sadness)... that's what I remember the most, because it looked like I had made something bad to her and the only thing I did was what the teacher said, to sit beside her, and then she made a scene, because no girl wanted to sit with me, and I was finally made to sit with a boy... but, well, no problem, it's normal, because girls are such crybabies.

Manuel initially keeps the dynamics of denial of interviewees, resorting to oblivion, loss of memory, but he acknowledges the fact, though he immediately ascribes it to the gender condition: fool girls, and minimizes it by pointing out that it was just a joke and their being small children. When questioned again by the interviewer to recite what had happened, Manuel expresses his sadness, along with the gesture of head lowering, and recognizes that he prefers to forget those painful remembrances. However, in view of the interviewer's insistence, he accepts to tell. He begins with the temporal location: it occurred in the past, long time ago; and he paradoxically continues with justification-like appraisals: "when I came I was new", where it is implicit that being a new student is a condition to be bothered, the so-called in Spanish "primiparadas" or practical jokes on new students played in school environments. He goes on with the appraisal of the situation, this time through indirect discourse, mentioning the surprise of the girls in the presence of the different: "no to have seen a little black before". He introduces the complicating action: "....and as soon as I came, they got stunned and the teacher made me sit on the desk beside one girl and she started crying". He interrupts the action to introduce an appraisal where he highlights the surprise of girls, and then concludes the action, also appraised this time, with gestures of sadness, that give the total tone to the narrative. He continues appraising his surprise by the girl's action in an absolutely common action, like sitting beside a classmate. He says he did not do anything wrong, only followed the teacher's directions, and then introduces the resolution of the narrative when he states that the teacher made him sit beside another boy, after no girl wanted to sit beside him due to the girl's scene. He closes the narrative with a coda, where he transposes the situation to the present: "no problem", but he continues appraising by ascribing a ritual character to the fact, and adding up connotations of gender: "normal, because girls are such crybabies". In this narrative we observe how Manuel detracts importance from the actions related to the conflict, resorting to the over-appraisal that minimizes the conflict.

Another way to minimize the conflict is by ascribing it to perceptive mistakes by mixedrace children. These mistakes could be simply corrected by resorting to the differences in the deeply internalized color scale:

A: Ah... I see, at the beginning... can you tell me more about the problem at the beginning? How... was it? How were you treated or what did they say?

B: Well... at the beginning I think it was by my skin color.

A: And what color was your skin?

B: I'm a little brown.

A: Little brown...

B: But they called me, it means, they called me chocolate...

A: Apart from that, what did they say?

B: They called me chocolate..., little black and... All these things concerning (.) little browns. Or what then (.) Well, I didn't take it, but I explained that I was not that color, because blacks are dark and I wasn't dark.

Laura follows the pattern of almost all the interviewees: denial, recognition, description. It was in the past, by the skin color, little brown; 
refusal to give details, perception mistake and resolution. For boys and girls the problem is not discrimination in itself, the problem is reduced to a misjudgment: "white" children do not establish differences in the skin color, which is determinant for black children.

\section{Ethnic insults}

\section{The basic ethnic category as an insult}

Once the first stages of perception of ethnic differences, of formation of appraisal of groups, are overcome, then the attitudes with respect to the different groups begin to crystallize and justification arguments are established. Children are barely aware of the conflicts of groups and their arguments are too incipient and are limited, as mentioned above, to the issue of color and other phenotypical traits. Therefore, when analyzing the contents it is observed that the problem is color, but not any color, the problem is the black color, so that the word "black" alone is laden with negative meaning and becomes the main ethnic insult, triggering the conflict.
A: What did she tell you?
B: That... that I was black... that... what?
That... that our race was... of I don't know what... well, said a lot of things. I don't remember.
A: And why did this happen or what? In what situation or what? If you... I guess, you weren't doing anything to her.
$B$ : It happens that there was a contest at school for the best reader, then I turned out to be elected in my course, in my class, then... a girl... a child had to... had to... pick her out, then, as I won the contest, she began treating me badly. Because I had won, cause I was a black, cause whatever. I didn't say anything, because nobody would like to be treated like that.

Tania introduces a narrative to talk about the classmates that mistreated her. She introduces the school context and the characters: she and another classmate; situation: a reading contest; complicating action: she won the contest, and resolution: the classmate began mistreating her telling her black. She appraises through indirect discourse: by means of the set phrase "and this and that", and she goes on with the resolution where she positions herself as a pacific person, victim of ethnic insult. She concludes with the phrase: nobody would like to be treated like that. However, the reported mistreatment is limited, at least implicitly, to the name "black".

\section{They call me black}

The same happens with Romario who indicates that the problem occurs when he is called black:
A: And what do they say or do?
$B:$ They call me black.
A: And why do they call you so?
B: ... I don't know.
A: Has it happened several times?
B: No.
A: You were telling me that... what do they do?
B: They call me black.

Children at these stages, maybe as a mechanism of defense, reduce the ethnic problems to the issue of color. Black is the marked element and holds a negative load. However, children also distinguish the problem from the context of enunciation. It is not the same a "black" said by a friend as "black" said by a stranger, as Juan explains:
A: What do you think about nicknames?
$B$ : Like calling names?
A: Yes, have you ever been called names by your classmates?
B: Ah, well, sometimes they call me the black or the little black.
A: How did you feel when they called you little black instead of your own name?
B: Well, I think this is normal, because they do it as parceros (buddies).
A: And if you are called so by someone that is not your parcero?


B: No way, because this is just between close friends or else it is like an insult or a bad word, do you understand?

\section{Nicknames}

Nicknames are another example of ethnic insult.

A: Have you ever been called nicknames by your classmates?

B: Some boys, the most tiresome in the class, they call me little black. I've already told the teacher and she tells them they must respect me; that it's not right to call me little black, they are bullies and I don't tell them bullies. And, well, my bother keeps telling me... dark and smoke hair (looking down).

For María, the diminutive little black, that is sometimes recognized as a warm word, becomes annoying, as motive for laughter and jokes by her classmates. Therefore, diminutives in pragmatic terms become indicators of affectionate treatment, but also respond to underlying forms of racism. María claims the right to have her given name as all the other boys and girls who are not called "whites" as an offense.

\section{Resisting conflicts}

\section{Group as a form of resistance}

Children establish different ways to resist the conflictive relations, or those perceived as problematic in the group relations at school. The most frequent one is the constitution of groups against a white majority.

A: Have you ever felt rejected by your classmates because of your ethnicity?

$B$ : The truth is I keep along with almost everyone, but some other children do not keep along with some girls in the class because they keep saying: Oh, no, I won't sit beside that black, because he smells bad and so on, but this is a lie, because they don't smell bad, but they don't have their group so they keep on them. I certainly get well with Nicolás, besides I already have my "parchecito" (group) then they don't bother me, but I don't like others to bother the other Afros in the class, but if I get into that, they're going to bother me too, so I rather not get into trouble, because I have a bad temper ...

The composition of the group can be inter-ethnic; what is important is that the other is prepared, even to fight. Not having a group is a synonym of being bothered. The logic of the group, however, does not imply ethnic solidarity. Each one solves one's own problems. This logic even applies to the same black classmates:

A: Do you have nigger classmates?

B: Well, of course, and we all dance, ah, except for this queer Jaime... (laughing)

A: Why?

$B$ : Because of his being unable to dance, he doesn't honor the race, that's why he is queer, he knows I tell him that, no problem. (He reacts to the interviewers' surprise).

A: And what does he think about you telling him queer, just for being an Afro who can't dance?

B: Well, he can't even say anything because we're more (laughing)

With the expression "we're more", Jackson solves the problem. Jaime has no possibility against a group constituted by several children.

\section{I feel like an alien}

The group is not only a set of friends to talk or play, it is an element that determines belonging, being part of the majority or the minority: Being strange or equal. Or being, as this girl, said originally in English, almost an alien. Someone without a similar referent even within her very family. 
A: Do you like studying here?

B: I hardly like it here, because this school is large, I liked it better at school.

A: Why?

B: Because I had friend there and I didn't study with my brothers. He keeps telling me I'm black.

A: And is that something that bothers you?

B: Well, yes.

A: Why?

B: Because I don't know anybody else like me, sometimes I feel like an alien or something like that ... (laughing and looking upwards)

A: Like an alien?

B: Well, yes, something like that, because there's nobody like me, or my mother, or my family, I don't even have a single friend combed like me, I feel very different to all of them, but the Afro boys here have their group and so...

This sensation of not being like the others is shared by Jaime:

A: What other bad things have they done to you?

B: Well, here my classmates sometimes call me black Cirilo, because I'm bold and because of the color... I guess, I don't know, but that pisses me off. Sorry, I mean I don't like that, there in my village I was normal, here I'm like an alien, I'm different and even though I thought that being Jackson, Jean Pierre and the others here we could be united by the race, but no, they are used to that and I don't like it, they like being the clowns of the class and I can't bear that.

Being part of the majority is being normal, the others are strangers, different, aliens. The difference is not solved with finding some people like oneself, but these could opt for reinforcing their identity by joining the majority, accepting what they are expected to.

\section{Fighting against stereotypes}

Boys and girls react differently to interethnic relations. Some search mechanisms of defense to avoid conflicts, they accept the stereotypes ascribed to them, others resist them. This is the case of Jaime, who does not accept that he should behave like the other black boys who dance, play soccer or "behave like clowns":

A: Why do you say they're the clowns in the class?

B: Because it's so, haven't you caught them?, when girls tell them to dance, they dance, they are chased in a game telling they are monkeys and they're happy, besides I don't like doing that.

A: Do they bother you because of that?

B: Yes, it's that they... I don't know what happens with them... they think all Afros must play basketball and dance very well, and I don't like dancing, I'm not funny, they are the ones of the joke now and then, and they laugh at me because I'm not like that and they make up ugly things....

Jaime rejects behaving like other children. In a critical way he assumes that they have adopted the behavior others ascribe to them in order to laugh at them. He prefers to get away from them and get along with girls, who, as mentioned above, are ascribed the causes of the conflict for "being fool". He is aware this is not the solution to stop being bothered.

Resistance to the stereotype also implies resisting an unpromising future by assuming the role expected from them in the society.

\section{Who are you identified with?}

B: Yes, I identify myself more or less with teacher Elvia, l'd also like to be a teacher, I won't listen to Fernando my brother who says I was born to cook because I'm black, because 
whenever I study, nobody will take this away from me, not like him, who is only lazing around, and maybe he'll have to sell coconut cookies when he grows up (laughing).

\section{Jokes and laughter as escape routes}

Through the history of mankind, laughter has been considered a liberating element. In our interviews, boys and girls resort to laughter to make fun of themselves, of others, or of situations.

Jokes are used to play down the importance of the facts, to convert the tragic into comic:

A: Well, do you know what Afrodescendant means?

B: Well, coming from Africa, like the grand-grand-grand-grand-grandparents, I guess... this is what we saw in class and such and such, even some videos, but it was very hard for them, just because you little white men treated them very hard... I'm lying (laughing), not you.

This boy converts slavery into something comic, updates the event bringing it to the present, involving the interviewer and then releases her from the responsibility of mistreatment.

In the following fragment, Jaime, when faced with the question of ethnic differences, opts for recalling the scene or a TV program, Sesame Street, he sings the refrain, and laughs, somewhat detracting the serious tone from the current topic:

A: Would you like to be with more people of your own race, like Chocó?

B: Well, yes.

A: Why?

B: Because we are all equal there and we are not badly treated, like here, where you feel very strange, like the song: (singing) one of us is not like the others... (laughing)

The others, the white, are also subjected to jokes and laughter:
A: Have you got a best friend in your class? B: Yes, of course, it's Nicolás, because we've been sitting together on the same desk two years ago and besides we are the tallest in our class.

A: Is he an Afro-Colombian?

B: No way, Nicolás is whiter than milk (laughing), I'm lying, he is... white and his mother too.

\section{Final reflections}

Provided that my idea is not to confirm or apply pre-established theories or categories, I limit myself to the voices of the children in order to deepen, from the collected data, into the complexity of the topic of ethnic identity constructions.

I will begin with the role of discourse in the production and reproduction of racism and as speakers' resource to construct their identities. From a repertoire of conversation, topic, interaction, lexical selection possibilities, children along with interviewers start bargaining senses. These are short stage performances where everyone aims at keeping one's own "face", although it is not always possible.

The interpretations below, as a form of provisional conclusions, pose a different writing style to that used so far in this article. This writing style tries to build a kind of integrative narrative which uses the first person singular "I" to account for the voices of the children interviewed

\section{Constructions of ethnic identities}

The constructions of ethnic identities among interviewed black boys and girls are created in a context of difference, where the majority is white. The sensory recognition of the difference makes color a key element of the interaction. Black, being the marked element, becomes taboo: it is not accepted, not spoken of and, therefore, unspeakable. I can escape from it 
through different color names or nuances. I deny its significance in inter-personal relations; I deny the conflicts caused by it or minimize its effects. I react when it is used to call me, I get offended, I complain or I suffer. I try to escape to its determinism by joining others under the idea of "more is better", confronting the stereotypes, affirming my difference, wanting to go to a better place, or laughing at it.

\section{Difference and quantity}

I am not like others. And in this relation, I am basically under numerical disadvantage. If we all were equal, there would be no problem. In my place of origin, we were all the same. But I am only one here, or maybe two or three, but no more, even within my family not all of us are the same. Difference. I am different to my dad, my brother or my sister. But I am black. I do not understand why others do not perceive it. Just watch. I am brown, light brown, cool brown, coffee, light coffee; not black, I am not black.

I dance, I amuse myself, and I entertain the others; I play soccer and I look like Michael Jackson. My ancestors were African and they had a very hard time and I am proud of my past and of my place of origin; nice land, where nobody humiliates the other. I wish I could return there! I do not want to be different. Why do not they understand that I am black, that my face is not like theirs. I do not want to be different. I want to be pretty like the other girls. I want to have straight hair and white face. And nobody to bother me.

However, nobody bothers me. Other children are bothered, not me. They could bother me because I am black; sometimes they have. Color. They call me this and that and so and so and they say... a lot of things, I do not remember, I forgot. But girls, it is just that they are fool and they cry and it seems I had made something bad to them, but no. It is about color. But I explain that is not my color; that little blacks are dark and I am not dark.
They called me black; they called me black and nobody likes to be treated like that. They also called me chocolate and smoke hair. I do not like that, because we must call everybody by the given names, not color, I do not call them little whites.

Since I have my group, my gang, then they do not bother me, we are more. Quantity. But girls do not play with me because I am black and am not pretty. If I had a group to defend me. Quantity. In front of them, I feel like an alien. Nobody looks like me. Difference. I have not a single classmate combed like me. I feel different, but the Afro children here have their group. I am like an alien here, I am different. Difference.

I thought that I and the others would be joined by race, but they like to be the clowns of the class and I can't stand it. Difference. When girls tell them to dance, they dance, they chase them in a game telling them they are monkeys and they are happy, moreover I do not like to do that. If I could return where I was born. Where all are like us. Quantity. Forgetting everything.

Sometimes it feels very strange, as if: one of us is not like the others. Just because you little white men are very bad, you treat us very hard! I'm lying, not you!

\section{Approximation to the concept of ethnic identities among boys and girls}

In this sense, I understand ethnic identities among boys and girls as the representations constructed by the subject on him/herself from the relations with others, different as to color, and depending on the context, different in quantity.

\section{Final Thoughts}

Ethnic identity constructions are thus determined in these first education stages by the identification of the differences and their overappraisal. Maybe we should stop there for a while, not only children, but also adults, researchers, 
political activists and other social agents. I wonder if it would not be better to focus on those aspects that make us similar, those aspects that make all of us equal in humanity and dignity. To leave aside for a while the marking of differences and transcend them towards the acknowledgement of human dignity.

\section{References}

Bruner, J. (1994). Life as narrative. Social Research, 71 (3) 691-710.

Garrido, A. y J. Álvaro (2007). Psicología social. Madrid: McGraw Hill.

Hall, S y P. du Gay (comp.) (1996). Cuestiones de identidad cultural. Buenos Aires: Amorrortu.

Restrepo, E. (2007). Identidades. Planteamientos teóricos y sugerencias metodológicas para su estudio. Revista Jangwa Pana. Pp. 24-35. Versión electrónica http://www.ram-wan.net/restrepo/ documentos/identidades-jangwa\%20pana.pdf. Revisada el 10 de marzo de 2011.

Molina, M. y A. Vargas (2009). La constitución de la identidad racial de niños y niñas afrocolombianos a partir del lenguaje que circula en la escuela. Monografía presentada en la Universidad Distrital.
Licenciatura en pedagogía infantil. Dirigida por Sandra Soler. Mención tesis laureada.

Smith, C. (2002). Aportes a la comprensión de la identidad étnica en niños, niñas y adolescentes de grupos étnicos minoritarios. En Ciencias sociales, Junio, Vol. II., número 96. Versión electrónica: http://redalyc.uaemex.mx/src/inicio/ArtPdfRed. jsp?iCve=15309606 Revisada el 4 de mayo de 2010 .

Santiesteban, N. (2005). Dinámicas discursivas del racismo en Bogotá. Monografía presentada en la Universidad de los Andes. Dirigida por Alcira Saavedra.

Soler, S. (1999). Conductas y actitudes lingüísticas en la comunidad indígena inga". Thesaurus. Bogotá, ICC. Pp. 911 - 979.

---- (2008) Pensar la relación Análisis crítico del discurso y educación. El caso de la representación de indígenas y afrodescendientes en los manuales escolares de ciencias sociales en Colombia. Discurso y sociedad. 2008. Vol. 2, No. 3. http:// www.dissoc.org/ediciones/v02n03/DS(2)Soler.html

Soler, S y N. Pardo (2007). Discurso y racismo en Colombia. Cinco siglos de invisibilidad y exclusión. En Teun V. Dijk (ed.). Discurso y racismo en América latina. Barcelona: Gedisa.

Tajfel, H. (1984). Grupos humanos y categorías sociales. Barcelona: Herder.

THE AUTHOR

SANDRA SOLER holds a doctoral degree in Linguistics and Communication. She is a researcher at Universidad Distrital Francisco José de Caldas interested in discriminatory discourses and schooling. She is currently working on the project Alternativa which understakes curriculum construction for teachers based on diversity. 